特集 17

ATPを用いた化学療法の抗腫瘍効果増強に関する実験的研究

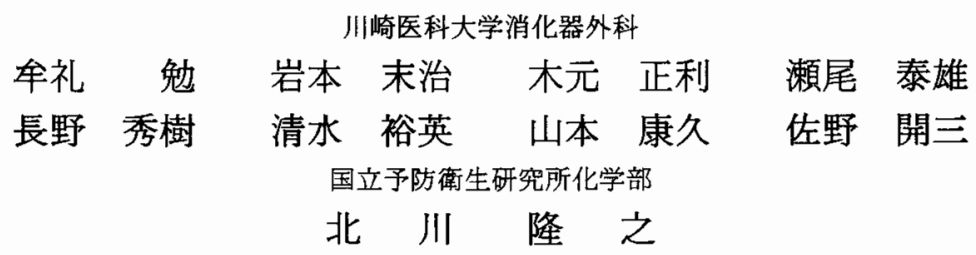

\title{
EFFECT OF ATP ON ANTITUMOR ACTIVITY OF VARIOUS ANTITUMOR DRUGS IN MICE TUMOR CELLS IN VITRO
}

Tsutomu MURE, Sueharu IWAMOTO, Masatoshi KIMOTO,

Yasuo SEO, Hideki NAGANO, Hirohide SHIMIZU,

Yasuhisa YAMAMOTO and Kaizo SANO

Division of Gastroenterology, Department of Surgery, Kawasaki Medical School

\section{Takayuki KITAGAWA}

Department of Chemistry, National Institute of Health

マウス培養細胞を用い, ATP の癌細胞叔よび正常細胞の増殖, 膜透過性におよぼす影響を検討し た.ささらに本物質の癌化学療法への応用を目的として, 各種抗癌剂との併用実験を行った. ATPによ り, 癌細胞では著明な細胞膜透過性の亢進, cell viability の低下がみられたのに対し, 非癌化細胞に おけりこれらの変化は軽微で, ATP 作用は癌細胞に特異的であった. ATP 処理後の癌細胞における 各種抗癌剂の抗腫瑒効果は, 5-FU, ADM, MMC, ACNU では相加的, VCR では相乗的に増強した。 また, 正常細胞に対する抗癌㓮の細胞毒性はATP の併用により増強されなかった。 これらの結果から ATPを用いることにより, 選択的癌化学療法が期待できるものと思われた.

索引用語：ATP, 細胞膜透過性, 癌化学療法

I.はじめに

抗癌風の癌細胞に対する選択性を高めることは, 癌 化学療法において重要な課題である.

われわれは, adenosine $5^{\prime}$-triphosphate (ATP) が 癌細胞に対して特異的に作用し, 膜透過性の克進, さ らに viability の低下を誘導する事実をるとに, 各種抗 癌剤との併用実験を in vitroで行い, 癌化学療法への 応用の可能性を検討した。

\section{II. 実験方法}

癌細胞はマウスの黒色腫である Clone-M3 細胞と Ehrlich 腹水癌細胞を, 非癌化細胞は NIH 3T3細胞と

*第30回日消外会総会シンポ 2 : 消化器実験外科の進 歩と新しい展開

$<1987$ 年10月12日受理 >別刷請求先：牟礼 勉

干701-01 倉敷市松島577 川崎医科大学消化器外科
$\mathrm{Balb} / \mathrm{c}$ マウス胎児線維芽細胞を実験に用いた。 Clone-M3 細胞は Ham F10+15\%馬血清 $+2.5 \%$ 胎児 牛血清で, Ehrlich および胎児線維芽細胞は Eagle $\mathrm{MEM}+10 \%$ 胎児牛血清で, NIH 3T3細胞は Eagle $\mathrm{MEM}+10 \%$ 成牛血清で, $37^{\circ} \mathrm{C}, 5 \% \mathrm{CO}_{2}$ 下で培養して いるものを使用した。

\section{1. 細胞膜透過性の検討}

ATPによる細胞膜透過性変化に関する実験は本 来, 細胞膜に非透過性であるリン酸化合物の細胞内一 の流入と, 細胞外への流出を指標として行った ${ }^{2) 4)}$.

1) p-nitrophenyl phosphate (pNPP) の細胞内への 流入を指標とした実験

pNPPは細胞膜を通過しにくい性質を持つ物質で あるが,膜を通過し細胞内に入ると, 細胞内の alkaline phosphatase により加水分解され, p-nitrophenol とな 
り黄色に呈色し, 再び膜を通過して細胞外に流出する.

この反応を利用し，細胞を $\mathrm{pH} 7.5$ たは8.2の Tris

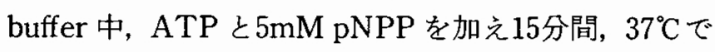
incubate した，細胞を除外し， buffer の呈色を分光光 度計 $(410 \mathrm{~nm})$ で測定した。

2）酸可溶性リン酸化合物質の流出を指標とした実 験

対数期の細胞の酸可溶性物質を培養液中, $\left[{ }^{3} \mathrm{H}\right]$ uridine で 3 時間ラベルすると, 細胞内に取り込まれた uridine はUDP, UTP とリン酸化され, 細胞膜を通過 できなくなり細胞内に保持される。このような標識細

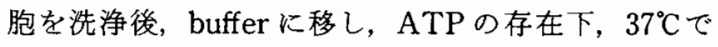
incubate した. 反応後, filter を通して bufferより細胞 を除外し，細胞外に流出した放射活性を測定した。 た，ラベル後の細胞内全酸可溶性物質は $5 \%$ TCA に て処理後, 同様に放射活性を測定した。
2. cell viability の検討

細胞を $\mathrm{pH} 7.5$ なな8.2の buffer 中, ATPを加兄 て10 20分間反応させ, 処理細胞を洗浄後, 通常の培 養液中, 72時間 incubate し細胞数を count した。

3. ATP と抗癌剤の併用効果の検討

2 の実験と同様, pH 8.2の buffer 中, 0.5mM ATP で10分間处理した細胞を, 抗癌剤を含む培地に移して incubate し, cell growth を検討した.

\section{III. 結 果}

$\mathrm{pNPP}$ の流入，加水分解を指標とした透過性変化 は, 癌細胞である Clone-M3, Ehrlich 細胞の両者で確 認された。 ATPが高濃度になるに従いpNPPの加水 分解が増加し, 細胞膜透過性の六進を示した。また, この反応は, bufferの $\mathrm{pH}$ に依存し, 8.2のアルカリ側 に強い反応がららた（図 1).

Clone-M3細胞に括ける酸可溶性物質の流出を指標

図 1 pNPP の流入, 加水分解を指骠とした細胞膜の透過性変化

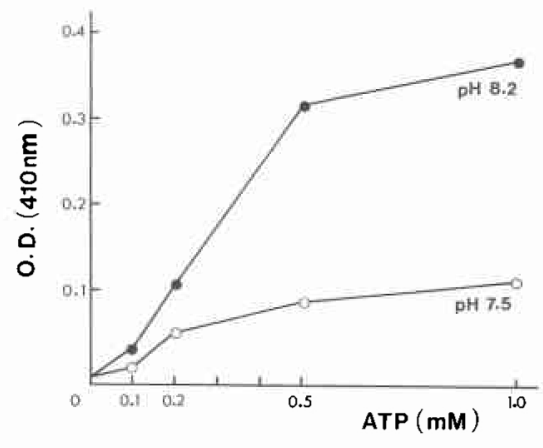

a . Clone-M3 cells

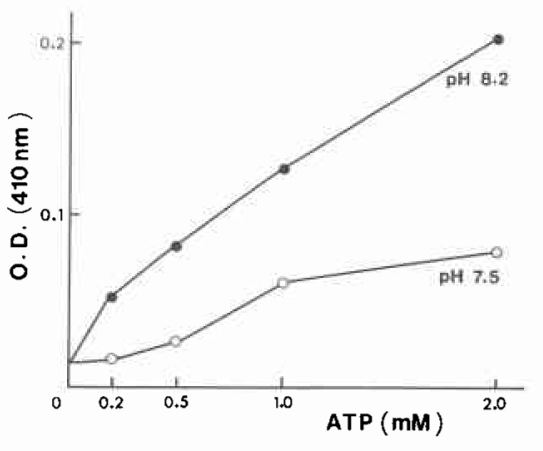

b. Ehrlich ascites cells

図 2 酸可溶性物質の流出を指標とした細胞膜の透過性变化（Clone-M3細胞）

a) Concentration of ATP and pH dependency

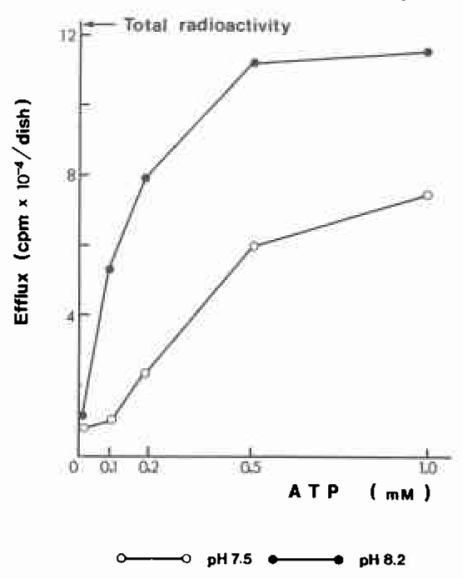

b) Time course

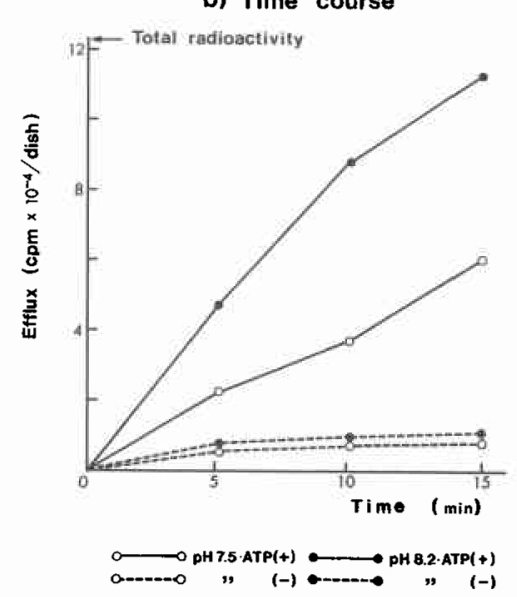


とした細胞膜透過性の变化は，先の流入を指標とした 実験と同様, ATP 添加後数分以内におこり，15分時, $\mathrm{pH} 8.2$ では $98 \%$ の流出が認められた。この変化は, $\mathrm{pH}$ 7.5ではゆるやかであり, 同じ15分時, $48 \%$ の流出がみ られた。 また，この反応は ATP $0.1 \mathrm{mM}$ で誘導され， 至適 ATP 濃度は, 0.5 1.0mM であった.これらの結 果は, ATPによる細胞膜透過性変化が物質の流入, 流 出両機構に同時に起きることを示している（図 2).

癌細胞と非癌化細胞の透過性変化を比較すると, 0.5 mM ATP で15分処理時, 癌細胞である Clone-M3細胞 では, ATP 末処理の10.6倍, 細胞内全酸可溶性物質の $98 \%$ の流出がみられたのに対し，非癌化細胞である NIH 3T3では, 1.8倍, 36\%，マウス胎児線維芽細胞で は1.6倍，19\%といずれる低值で，ATPの作用は用い た癌細胞に極めて特異的であった（図 3 ).

ATP 処理を行った Clone-M3細胞の viability の変
化を regrowth assayにより調べた結果, 膜透過性変 化と同様, ATP 処理した Clone-M3細胞の viability

因 3 癌細胞と非癌化細胞の透過性変化

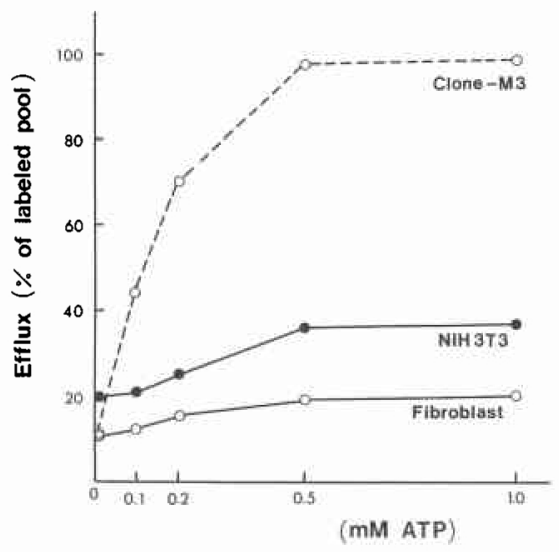

図 4 ATPによる cell viability の変化（Clone-M3細胞）
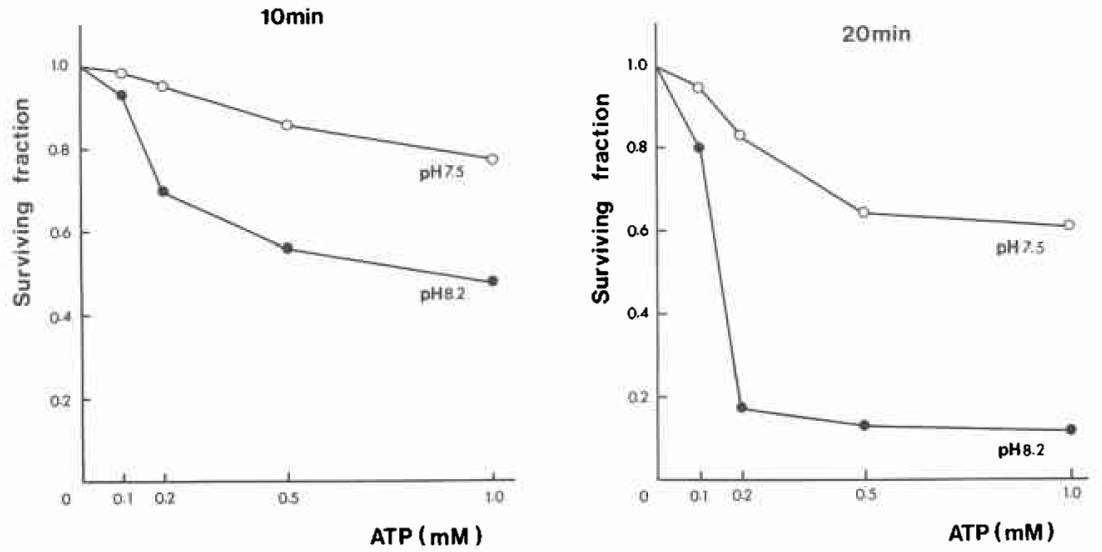

図 5 ATPによる cell viability の変化（NIH 3T3，マウス胎児線維芽細胞）
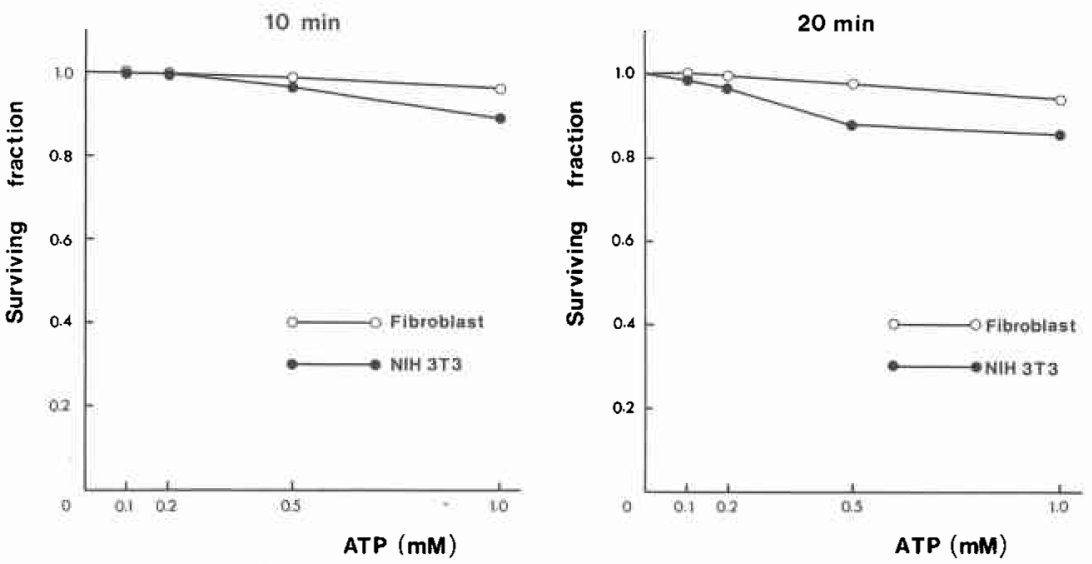
表 1 抗癌剂の抗腫瘍効果に及ぼすATP の影響

\begin{tabular}{|c|c|c|c|}
\hline \multirow{2}{*}{ Drugs } & \multirow{2}{*}{$\begin{array}{c}\text { Dose } \\
(\mathrm{ng} / \mathrm{ml})\end{array}$} & \multicolumn{2}{|c|}{ Survival rate $(\%)$} \\
\hline & & $\overline{\text { ATP }(-)}$ & $\overline{\text { ATP }(+)}$ \\
\hline 5-FU & $\begin{array}{r}(-) \\
100 \\
1.000 \\
10.000 \\
100.000\end{array}$ & $\begin{array}{r}100.0 \\
93.4 \\
69.7 \\
25.1 \\
24.9\end{array}$ & $\begin{array}{l}51.0 \\
50.4 \\
34.7 \\
13.7 \\
12.1\end{array}$ \\
\hline ADM & $\begin{array}{r}(-) \\
1 \\
10 \\
100 \\
500\end{array}$ & $\begin{array}{r}100.0 \\
70.9 \\
32.6 \\
27.0 \\
2.5\end{array}$ & $\begin{array}{r}48.1 \\
35.9 \\
16.0 \\
11.6 \\
0.5\end{array}$ \\
\hline MMC & $\begin{array}{r}(-) \\
10 \\
100 \\
1.000\end{array}$ & $\begin{array}{r}100.0 \\
66.4 \\
24.7 \\
19.7\end{array}$ & $\begin{array}{l}52.1 \\
35.8 \\
13.5 \\
10.6\end{array}$ \\
\hline ACNU & $\begin{array}{r}(-) \\
10 \\
100 \\
1.000 \\
10.000\end{array}$ & $\begin{array}{r}100.0 \\
94.6 \\
89.0 \\
20.7 \\
16.9\end{array}$ & $\begin{array}{r}47.5 \\
46.3 \\
40.8 \\
10.2 \\
8.8\end{array}$ \\
\hline VCR & $\begin{array}{c}(-) \\
0.1 \\
1 \\
5 \\
10\end{array}$ & $\begin{array}{r}100.0 \\
96.2 \\
77.2 \\
25.6 \\
18.0\end{array}$ & $\begin{array}{c}45.7 \\
33.4^{*} \\
26.9 * \\
9.8 \\
7.8\end{array}$ \\
\hline
\end{tabular}

* Synergistic effect

は, ATPが高濃度になるに従い，また処理時間が長く なるに従って低下した（図4）.

一方，非癌化細胞である，NIH 3T3，マウス胎児線 維芽細胞では, 膜透過性変化と同様, ATP 処理による 増殖抑制は極めて少なかった（図 5 ）.

以上の知見をもとに，ATPによる膜透過性の六進 ならびに殺細胞効果が，抗癌剤の抗腫瘍効果に及ぼす 影響をさらに検討した. Clone-M3細胞に执いて ADM と併用した結果をみると, ADM の抗腫瘍効果は, いず れの濃度においても ATPで処理することにより相加 的に増強された。すなわち, $1 \mathrm{ng} / \mathrm{ml}$ の ADM 単独では $70.9 \%$, ATP 処理のみでは48.1\%の生存率であった が，両者の併用により生存率は $35.9 \%$ と低下した。

5-FU, MMC, ACNUを併用した場合も同様に相加 的効果がみられた，VCR ではわずかながら，相乗的に 増強された（表 1 ）。

同様の実験で，正常細胞であるマウス線維芽細胞と 癌細胞である Clone-M3細胞を比較すると，マウス線 維芽細胞では，ATPの作用はほとんど認められず, ADM, VCR のいずれの濃度においても, Clone-M3細 胞に比べ生存率は有意に高かった（図 6).

\section{IV. 考察}

細胞外 ATP が，動物細胞の膜透過性変化を扎こす ことは、これまでにもいくつかの報告がある(1)316). 現 在までに, 3T6, SV3T3, PY3T3, B16 melanoma, L929, Friend erythroleukemia などのマウス由来の癌
図 6 癌細胞と正常細胞における ATP の併用効果
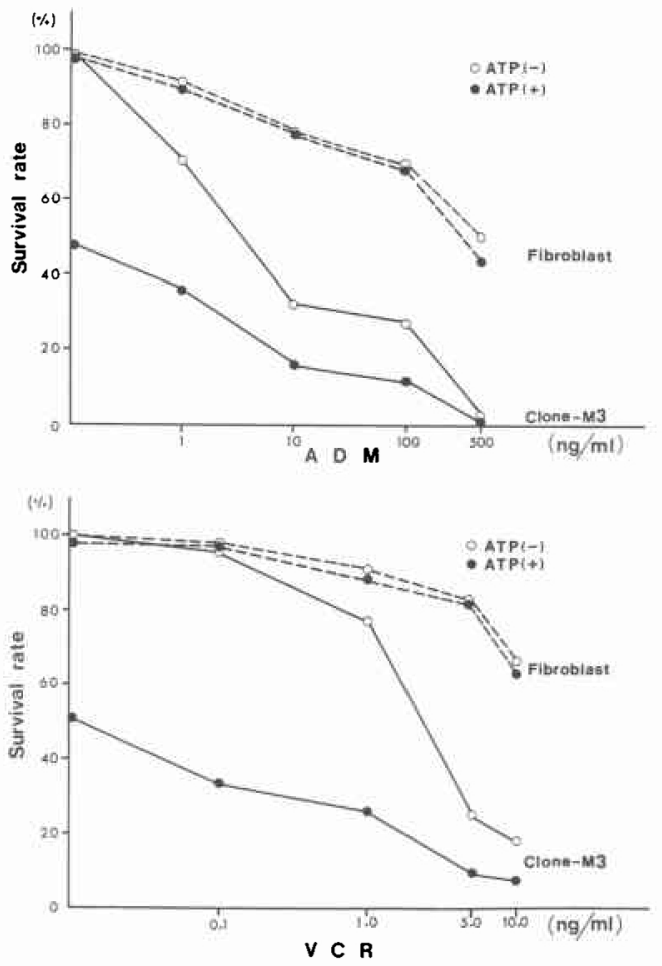

細胞をはじめ, CHO-Kl（ハムスター)や $\mathrm{HeLa}$ (ヒト) 細胞などの種々の癌細胞で ATP 作用が認められてい る.今回の㬰験では, 癌細胞である Colne-M3, Ehrlich 細胞において ATP 作用が確認され，また膜透過性の 亢進に伴い cell viability の低下も認められた。しか し, 非癌化細胞である NIH 3T3, マウス胎児線維芽細 胞ではこれらの変化は軽裂であり，ATPの作用は用 いた癌細胞に特異的であった。

また, 癌細胞に拝ける各種抗癌昘の増殖抑制効果は ATP 処理により相加的, 一部, 相乗的に増強された. ATPがすべての正常細胞に対して殺細胞効果を発揮 しないとすれば，ATP の併用により少量の抗癌剤で 癌の増殖を抑えることが可能となり, 副作用の軽減に もつながる.したがって, 臨床的に ATP の適切な投与 法を確立することで，これまでの化学療法に加えた治 療効果が期待できるものと思われ，現在 in vitro での 検討を行っている。

\section{文 献}

1) Rozengurt E, Heppel LA : A specific effect of external ATP on the permeability of transformed $3 \mathrm{~T} 3$ cells. Biochem Biophys Res Commun 
$67: 1581-1588,1975$

2) Rozengurt E, Heppel LA, Freiberg I: Effect of exogenous ATP on the perrmeability properties of transformed cultures of mouse cell lines.J Biol Chem $252: 4584-4590,1977$

3）北川隆之：ATPに上る動物細胞表面膜の透過性 調節。蛋白質・核酸・酵素 $29: 511-522,1984$

4）牟礼 勉：癌細胞の増殖・膜透過性に及注す外因 性 ATP の影響一In vitro にお梳討一. 川崎医
会誌 $12 ： 67-80,1986$

5）佐野開三，车礼 勉：畽瘍細胞に及ぼす外因性 ATP の影響。外科治療 $153 ： 578-579,1985$

6) Kitagawa $T$, Akamatsu $Y$ : Modulation of passive permeability by external ATP and cytoskeleton-attacking agents in cultured mammalian cells. Biochem Biophys Acta 734 : $25-32,1983$ 